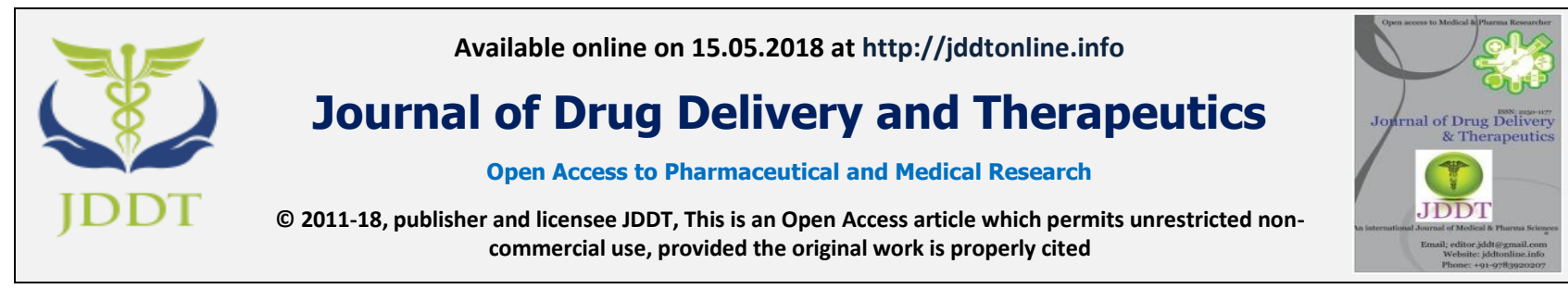

Open Access

Research Article

\title{
ASSESSMENT OF ANTIDIABETIC POTENCIAL OF LEUCAS CEPHALOTES SPRENG EXTRACT IN ALLOXAN INDUCED LABORATORY ANIMALS
}

\author{
Gayyurul Islam*, Kavita Gahlot \\ Faculty of Pharmacy, IFTM University, Moradabad, U.P., India
}

\section{ABSTRACT}

The objective of this study is to investigate the alcoholic extract of Leucas cephalotes for antidiabetic effects in laboratory animals. Diabetes was induced in rats by administration of alloxan $(120 \mathrm{mg} / \mathrm{kg}$ body wt.). In normal rats, alcoholic extract had significantly decreased the blood glucose level (BGL) in a dose-dependent fashion after repeated administration of alcoholic extract for 7 days. In alloxan-induced diabetic rats, the extract decreased the BGL with significant improvement in glucose tolerance and body weight at the end of I, II and III week after alcoholic extract treatment. These results suggest that alcoholic extract is having potent antidiabetic activity in comparison with normal as well in diabetic rats.

Keywords: Leucas cephalotes, Anti-diabetic activity, Blood glucose level

Article Info: Received 10 Feb, 2018; Review Completed 02 May 2018; Accepted 10 May 2018; Available online 15 May 2018

Cite this article as:

Islam G, Gahlot K, Assessment of antidiabetic potencial of Leucas cephalotes spreng extract in alloxan induced laboratory animals, Journal of Drug Delivery and Therapeutics. 2018; 8(3):109-115

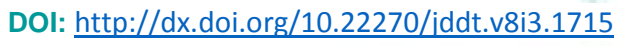

*Address for Correspondence: Gayyurul Islam, Faculty of Pharmacy, IFTM University, Moradabad, India

\section{INTRODUCTION}

The use of herbal drugs, extracts and plant based remedies has increased the 'green' revolution as herbal medicine is gaining popularity. Crude drugs which are obtained from the plant in the Core subject matter of Pharmacognosy are not only used for the treatment of various ailments but also in cosmetics, food and drug industries. The plants, are regaining the rightful place in treatment disease. Today's applied science of Pharmacognosy has a far better knowledge of the active ingredients and their prominent therapeutic activity on the human beings. Medicinal plants are of great value for treatment and cure of ailments since ancient times, however scientific research has expanded our knowledge of the chemical effects and composition of the active constituents, which is responsible for medicinal properties. It is universal fact that the plant based drugs and treatments are far safer than synthetic medicines to cure the complex diseases like Cancer and AIDS $^{1}$
Diabetes Mellitus (DM) is a chronic metabolic disorder characterized by a high blood glucose concentrationHyperglycemia (fasting plasma glucose $>7.0 \mathrm{~m} \mathrm{~mol} / \mathrm{l}$, or plasma glucose $>10 \mathrm{~m} \mathrm{~mol} / \mathrm{l}, 2 \mathrm{~h}$ after meal) due to Insulin deficiency and for insulin resistance. Hyperglycemia occurs due to hepatic glucose output and diminished uptake of glucose by skeletal muscle with reduced glycogen synthesis when the renal threshold for glucose reabsorption is exceeded, glucose spills over into the urine (glycosuria) and causes an osmotic diuresis (Polyuria) which in turn results in dehydration, thirst and increased drinking (Polydipsia).Low concentration of insulin causes wasting due to increased breakdown and reduced synthesis of proteins. The consequences of ketosis may occur in the absence of insulin as there is fast fat breakdown to Acetyl-COA. In the absence of aerobic carbohydrate metabolism, Acetyl-COA is converted anaerobically to acetoacetate etc $^{2}$.

As a consequence of the metabolic derangements in $\mathrm{DM}$, various complications may grow in body system. 
Many of these bad complications are due to diseases of blood vessels, improper functioning of the vascular endothelium and abnormalities of endothelium-derived mediators, RDS, protein kinase and non-enzymatic products of glucose and albumin have been implicated in these changes.

Diabetic neuropathy is considered as one of the disease, associated with accumulation of poorly metabolized osmotically active metabolites of glucose including sorbitol, produced by the action of aldose reductase ${ }^{3}$

There are two main forms of DM,

- $\quad$ Type I diabetes (also known as Insulin-dependent diabetes mellitus- IDDM- or Juvenile onset diabetes). Another type IIdiabeties

- Type II diabetes (also known as Non- Insulindependent diabetes mellitus- NIDDM- or maturity onset diabetes.

In type I diabetes the absolute deficiency of insulin due to autoimmune destruction of $\beta$ cells of langarhans occurs and due this, patient suffers from diabetic Ketoacidosis. Patients of type IDM are usually young. In type II diabetes, chances of insulin resistance and impaired regulation of Insulin secretions observed. Such patients are usually obese, adult and aged. Treatment of such DM cases initially stats with oral hypoglycemic drugs or Insulin often become necessary ${ }^{4}$.

The plant (Leucas cephalotes SPRENG) is distributed in Punjab, Bengal, Assam, Himalaya, Rajputana Desert, Gujarat and also in Afghanistan. It is an erect, scaberulous or pubescent, stout annual, $30-100 \mathrm{~cm}$ high found as a common weed in cultivated grounds and waste lands throughout the greater part of India ascending upto $1800 \mathrm{~m}$ in the Himalayas, leaves shortly petiolated narrowly ovate or ovate lanceolate, Crenate serrate. Flowers are small, white in dense terminal globose whorls, nutlets small, smooth brown ${ }^{5}$.

The plant has a pungent taste with a flavour. It is Laxative, anthelmintic, stimulant, Diaphoretic useful in bronchitis, jaundice, inflammation, Asthma, Dyspepsia, paralysis, Leucoma. The leaves are also useful in Fevers and urinary discharges. The fruit juice in certain localities can be applicable as an external application in scabies. The flowers are administered in the form of syrup as domestic remedy for coughs and colds. The leaves are used combination with other drugs are to treat scorpion bite but they are not being used to prepare the chemical constituent antidote to scorpion venom. The plant is also used in piles and malaria ${ }^{6}$.

From the whole herb of Leucas cephalotes Spreng, new Labdane, norlabdane and abietane- type diterpenes named Leucasdins $\mathrm{A}(1), \mathrm{B}(2)$ and $\mathrm{C}(3)$, respectively, and two protostane- type triterpenes named Leucastrins $\mathrm{A}(4)$ and $\mathrm{B}(5)$ were isolated, together with a known triterpene, oleanolic acid, five sterols, 7-oxositosterol, 7oxostigmosterol, 7 alpha- hydroxysitosterol, 7- alphahydroxystigmesterol and stigmesterol, and eight flavones, 5- hydroxyl- 7,4- dimethoxyflavone, pilloin, gonzolitosin, tricin, cosmosin, apigenin 7-0-beta-D-(6-0P-coumaroyl) glucopyranoside, Anisofolin $\mathrm{A}$ and
Luteolin 4-0-beta- D-glucuronopyranoside were isolated.

\section{MATERIALS AND METHODS}

\section{Materials}

\subsection{Plant material}

Whole plant of Leucas cephalotes were collected from Moradabad, U.P. and the plant samples were authenticated by Dr. Ashok Kumar, Botanist, IFTM University, Moradabad.

\subsection{Laboratory Animals}

Albino rats of either sex weighing between 150-200gm were employed for this investigation. All the protocols related with animal experiment were approved by Institutional Animal ethics committee (IAEC). All the chemicals were of AR grade and procured from $\mathrm{CDH}$ (P) Ltd, New Delhi.

\section{3 preparation of extract:}

Leucas cephalotes plants
$\downarrow$
Collected
$\downarrow$
Authenticated by taxonomist
$\downarrow$
Drying
$\downarrow$
Subjected to powdering
$\downarrow$

Subjected to suitable method of extraction

\section{Flow Chart showing Solvent extraction method}

The powder drug was extracted by the soxhlet extractor with successively different solvent, in increasing order of polarity.

\subsection{Preliminary phytochemical analysis:}

Extract was subjected to preliminary phytochemical investigation for detection of Triterpenes/ steroids, Flavonoids, Saponins, Reducing sugars and alkaloids.

\subsection{Determination of acute toxicity: (OECD, 2001)}

The acute toxicity of alcoholic extracts of Leucas cephalotes were determined by using female albino Wistar rats $(150-200 \mathrm{~g})$, were maintained under the standard laboratory conditions. The animals $(n=6)$ were fasted $12 \mathrm{~h}$ before the experiment, up and down procedures were adopted for toxicity studies. Animals were administered with single dose of extract of Leucas cephalotes at a dose of $2000 \mathrm{mg} / \mathrm{kg}$ and observed for their mortality during 2 and 7 days study period (short term) toxicity and the dose increased up to $5000 \mathrm{mg} / \mathrm{kg}$ b.w. and were observed up to 7 days for their behavioral, economical and neurological profiles except slight depression in their activity.

\subsection{Assessments of anti-diabetic activity in alloxan- induced diabetic rats:}

Alloxan monohydrate was dissolved in normal saline and administered i.v into fasted rats at a dose of 120 $\mathrm{mg} / \mathrm{kg}$ b.w. The freshly prepared solution was used for 
administration. The rats were given $5 \%(\mathrm{w} / \mathrm{v})$ glucose solution in feeding bottles for next $24 \mathrm{~h}$ in their cages to prevent hypoglycaemia after alloxan injection. After 72 $\mathrm{h}$ rats with $\mathrm{BGL}$ greater than $200 \mathrm{mg} / \mathrm{dl}$ and less than $400 \mathrm{mg} / \mathrm{dl}$ were selected and observed for hyperglycaemia (fasting blood glucose level -FBG) greater than $200 \mathrm{mg} / \mathrm{dl}$ and lesser then $400 \mathrm{mg} / \mathrm{dl}$ ) up to 7 days. Such animals were divided into six groups as follows:

Group 1: Normal control (distilled water $10 \mathrm{ml} / \mathrm{kg}$, p.o.)

Group 2: Control (Alloxan treated with $120 \mathrm{mg} / \mathrm{kg}$, p.o.)

Group 3: Standard group (Glibenclamide $10 \mathrm{mg} / \mathrm{kg}$, p.o.)

Group 4: Low dose (100 mg/kg, p.o.)

Group 5: Medium dose group (200 mg/kg, p.o.)

Group 6: High dose group (400 mg/kg, p.o.)

The treatment was continued for the next 21 days and blood samples were collected on $0^{\text {th }}, 7^{\text {th }}, 14^{\text {th }}$ and $21^{\text {st }}$ days after $1 \mathrm{~h}$ administration. BGL was estimated at various time intervals GOD/P.O.D. kit. Serum test was carried out on day 21 th was carried out.

\section{RESULT AND DISCUSSION}

\subsection{Preliminary phytochemical analysis of Leucas cephalotes}

Phytochemical investigation of Leucas cephalotes revealed that ethanolic extract (EE) contains phytosterols, fixed oils, alkaloids, flavonoids, saponins, phytosterols and phenolics.

The percentage yield of EE was $4.88 \%$.

\subsection{Hypoglycaemic activity in normal rats}

Fasting blood glucose (FBG) levels were found within the range of $95-105 \mathrm{mg} / \mathrm{dl}$ in all the groups at $0 \mathrm{~h}$. Single dose administration of EE (100, 200 and 400 $\mathrm{mg} / \mathrm{kg}$ ) did not decreased the FBG level at various time intervals viz. 1, 2 and $4 \mathrm{~h}$ after treatment, indicating that the extracts could not produce significant hypoglycaemic activity after acute treatment (Table 1). Repeated administration of EE had significantly reduced the FBG on $7^{\text {th }}$ day, $14^{\text {th }}$ day and $21^{\text {st }}$ day with 400 $\mathrm{mg} / \mathrm{kg}$ and on $7^{\text {th }}$ day, indicating that the EE is effective in treating $\mathrm{DM}$ in long term therapy. (Figure 1). Glibenclamide $(5 \mathrm{mg} / \mathrm{kg})$ significantly reduced blood glucose level after single dose and repeated dose administration as compared to control groups. Fasting blood glucose (FBG) levels in normal rats were in the range of $95-100 \mathrm{mg} / \mathrm{dl}$. Treatment with alloxan (120 $\mathrm{mg} / \mathrm{kg}$, i.v.) had increased the blood glucose level (BGL) to a range of $250-270 \mathrm{mg} / \mathrm{dl}$ after 7 days. Single dose administration of EE (100, 200 and $400 \mathrm{mg} / \mathrm{kg}) \mathrm{did}$ not significantly reduced the BGL in alloxan-induced diabetic rats, while Glibenclamide $(5 \mathrm{mg} / \mathrm{kg})$ significantly reduce the BGL at $1^{\text {st }} \mathrm{h}$ of $1^{\text {st }}$ day treatment.

Table 1: BGL after $0^{\text {th, }} 7^{\text {th }}, 14^{\text {th }}$ and $21^{\text {th }}$ day

\begin{tabular}{|l|l|l|l|l|l|}
\hline Treatment & Dose & $\mathbf{0}^{\text {th }}$ day & $\mathbf{7}^{\text {th }}$ day & $\mathbf{1 4}^{\text {th }}$ day & $\mathbf{2 1}^{\text {th }}$ day \\
\hline $\begin{array}{l}\text { Normal } \\
\text { control }\end{array}$ & Blank & $95.167 \pm 0.749$ & $93.500 \pm 0.428$ & $93.833 \pm 0.477$ & $94.500 \pm 0.500$ \\
\hline $\begin{array}{l}\text { Control }(3 \% \\
\text { v/v tween } 80)\end{array}$ & $10 \mathrm{ml} / \mathrm{kg}$ & $241.00 \pm 2.556$ & $255.167 \pm 0.401$ & $258.667 \pm 0.333$ & $265.167 \pm 0.401$ \\
\hline Glibenclamide & $10 \mathrm{mg} / \mathrm{kg}$ & $231.33 \pm 0.558 * * * *$ & $107.833 \pm 0.401 * * * *$ & $94.333 \pm 0.333 * * * *$ & $87.833 \pm 0.307 * * * *$ \\
\hline EE & $100 \mathrm{mg} / \mathrm{kg}$ & $237.33 \pm 0.760$ & $235.167 \pm 0.477 * * * *$ & $191.500 \pm 0.224 * * * *$ & $178.833 \pm 0.307 * * * *$ \\
\hline EE & $200 \mathrm{mg} / \mathrm{kg}$ & $238.667 \pm 0.558$ & $208.667 \pm 0.919 * * * *$ & $186.667 \pm 0.333 * * * *$ & $163.33 \pm 0.333 * * * *$ \\
\hline EE & $400 \mathrm{mg} / \mathrm{kg}$ & $233.667 \pm 0.211 * * * *$ & $201.833 \pm 1.922 * * * *$ & $141.167 \pm 0.477 * * * *$ & $102.167 \pm 0.872 * * * *$ \\
\hline
\end{tabular}

\section{$0^{\text {th }}$ day}

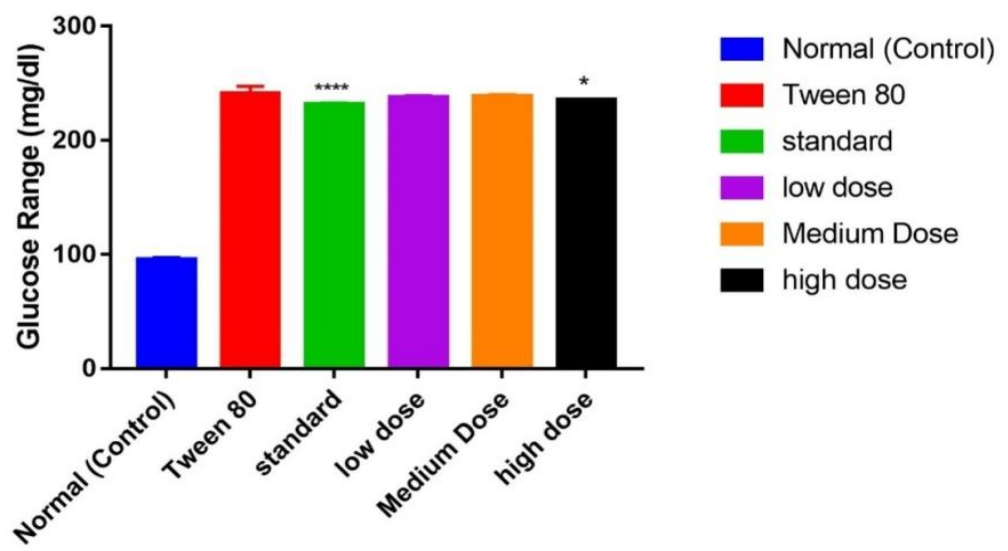

Treatment (mg/kg)

Figure 1: Glucose range in different treatment groups 


\subsection{Level of Urea, Creatinine, Total Protein, Serum albumin in animals}

Level of Urea, Creatinine, Total Protein, Serum albumin, $\mathrm{A} / \mathrm{G}$ ration was measured after $7^{\text {th }}$ day of administering the Alloxan and start of treatment in animals. After administering the Alloxan at a single dose of (120 $\mathrm{mg} / \mathrm{kg}$, i.v.) the level of Urea, Creatinine, Serum albumin was incresed in comparison to normal control but the level of total protein was reduced significantly.
The standard Glibenclamide had reduced the level of Urea, Creatinine, albumin:globulin ration. The total protein and serum albumin was increased significantly in Glibenclamide treated group (control group). (Table 2)

The findings suggested that $\mathrm{EE}$ in dose dependent fashion increased the concentration of total protein and serum albumin. The $\mathrm{EE}$ in dose dependent fashion reduced the level of urea leel, creatinine level and $\mathrm{A} / \mathrm{G}$ ratio (Fig 2-9).

Table 2: Level of urea, creatinine, total protein,Serum Albuminin animals

\begin{tabular}{|l|l|l|l|l|l|}
\hline Treatment & Urea Level & $\begin{array}{l}\text { Creatinine } \\
\text { Level }\end{array}$ & Total Protein & $\begin{array}{l}\text { Serum } \\
\text { Albumin }\end{array}$ & A/G ratio \\
\hline Normal control & $30.950 \pm 0.675$ & $0.76 \pm 0.01$ & $6.42 \pm 0.12$ & $4.30 \pm 0.01$ & $1.95 \pm 0.01$ \\
\hline $\begin{array}{l}\text { Control } \\
\text { (3\% v/v tween 80) }\end{array}$ & $84.435 \pm 1.330$ & $2.02 \pm 0.04$ & $2.59 \pm 0.18$ & $1.86 \pm 0.02$ & $3.66 \pm 0.14$ \\
\hline Glibenclamide & $45.290 \pm 1.713^{* * * *}$ & $0.98 \pm 0.01^{* * * * *}$ & $6.06 \pm 0.02^{* * * * *}$ & $3.78 \pm 0.06^{* * * * *}$ & $2.06 \pm 0.2^{* * * * *}$ \\
\hline EE (100mg/kg b.w.) & $80.905 \pm 0.320^{* *}$ & $1.71 \pm 0.01^{* * * *}$ & $3.18 \pm 0.01^{* * * *}$ & $1.48 \pm 0.07 * *$ & $3.10 \pm 0.05^{* * *}$ \\
\hline EE (200mg/kg b.w.) & $71.640 \pm 0.523^{* * * * *}$ & $1.58 \pm 0.02^{* * * * *}$ & $4.19 \pm 0.01^{* * * * *}$ & $2.27 \pm 0.11^{* *}$ & $2.81 \pm 0.05^{* * * * *}$ \\
\hline EE (400mg/kg b.w.) & $48.980 \pm 0.233^{* * * * *}$ & $1.01 \pm 0.08^{* * * * *}$ & $6.46 \pm 0.02^{* * * * *}$ & $3.12 \pm 0.04 * * * *$ & $2.13 \pm 0.03^{* * * * *}$ \\
\hline
\end{tabular}

\section{Statistical analysis:}

Data were expressed as mean \pm SEM. Significance was calculated using one way ANOVA followed by Dunnet's multiple comparison tests compared to control.

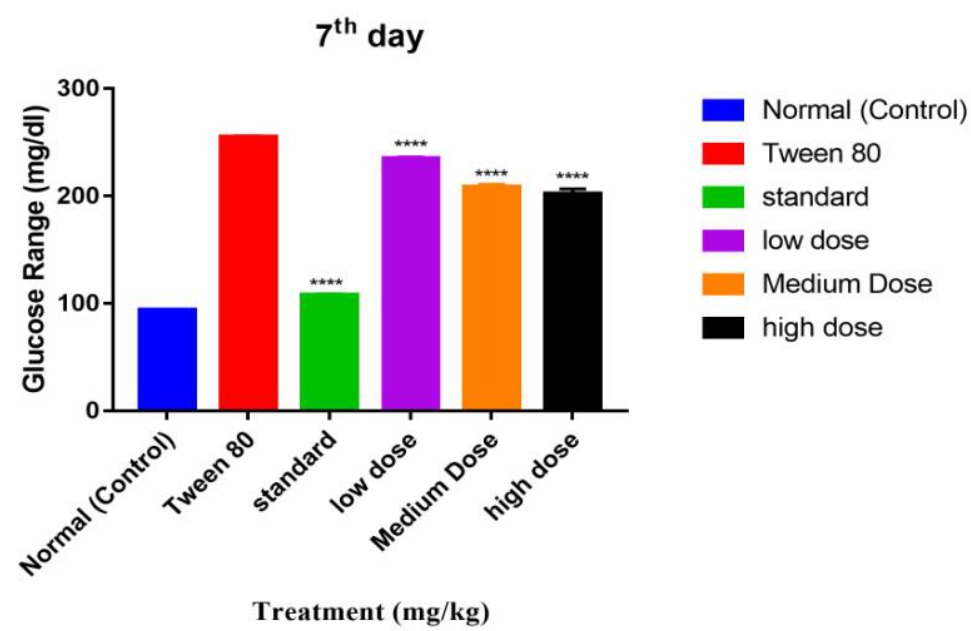

Figure 2: Blood glucose range in different treatment group on 7 th day.

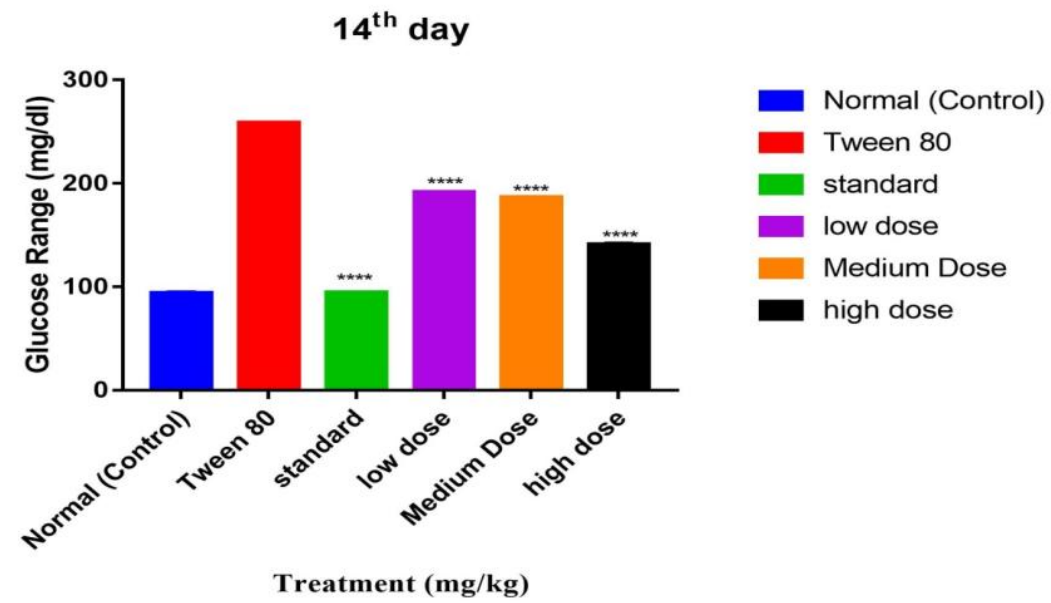

Figure 3: Blood glucose level range in different treatment groups on $14^{\text {th }}$ day. 


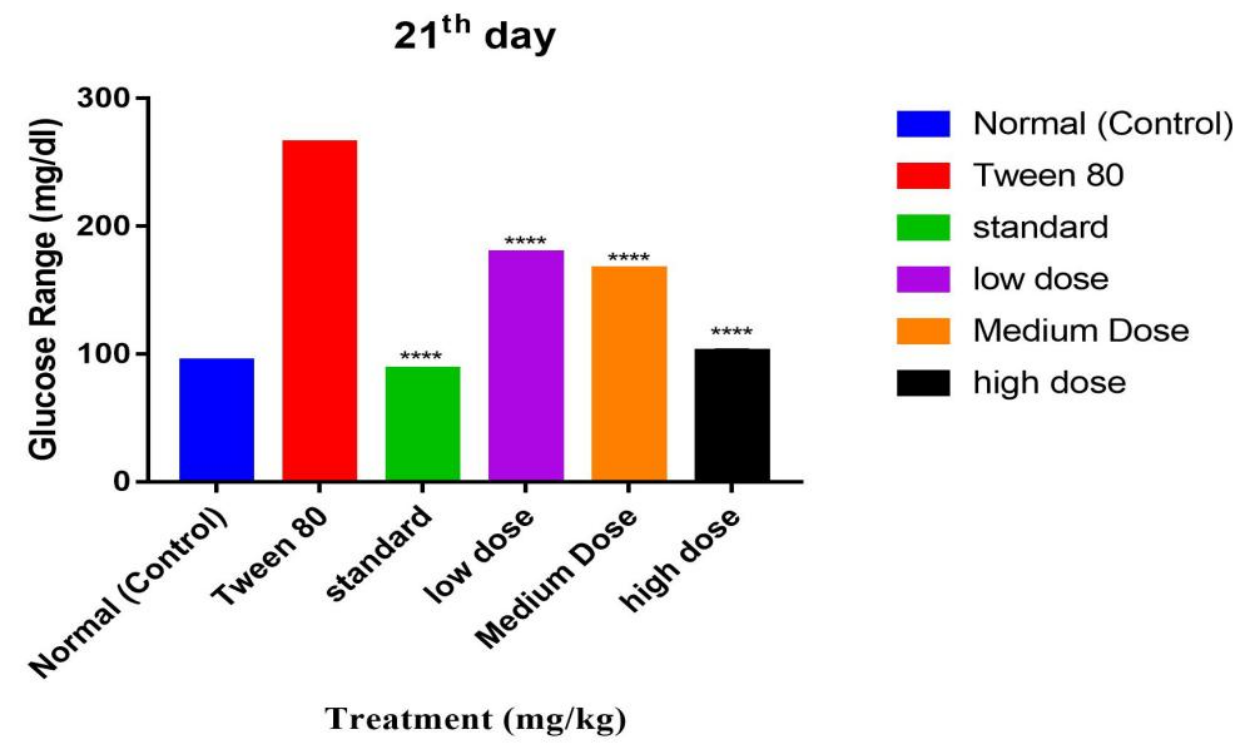

Figure 4: Blood glucose level range in different treatment groups on $21^{\text {st }}$ day.

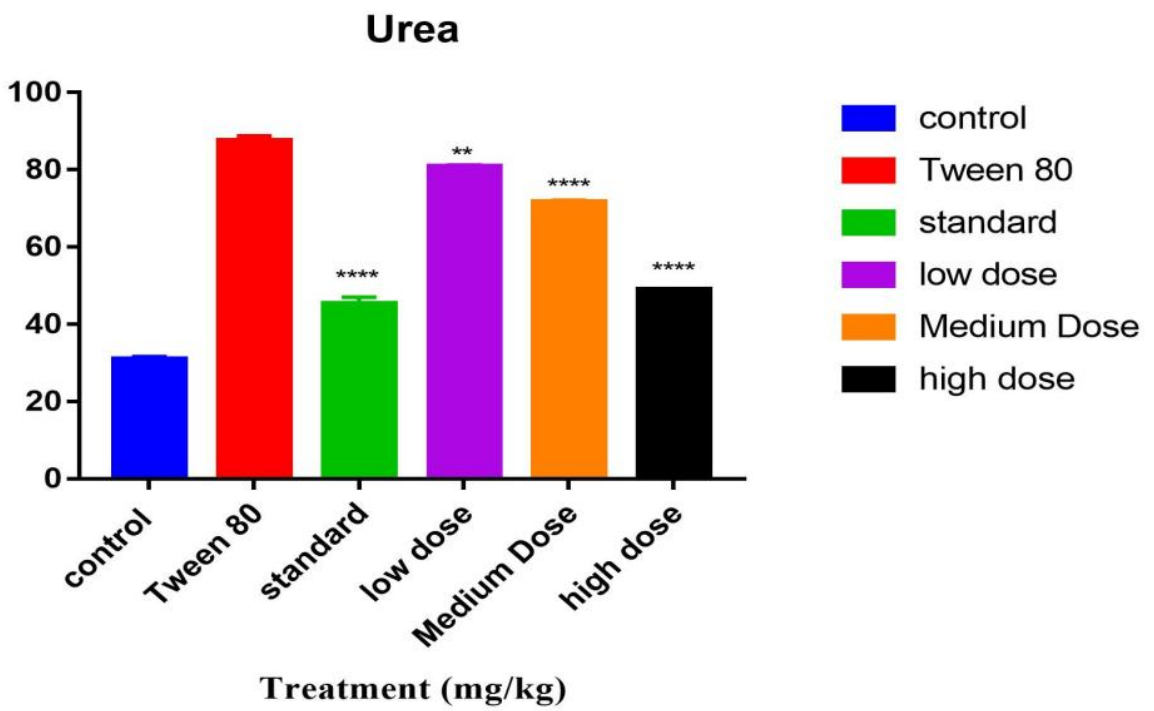

Figure 5: Urea level in treatment group.

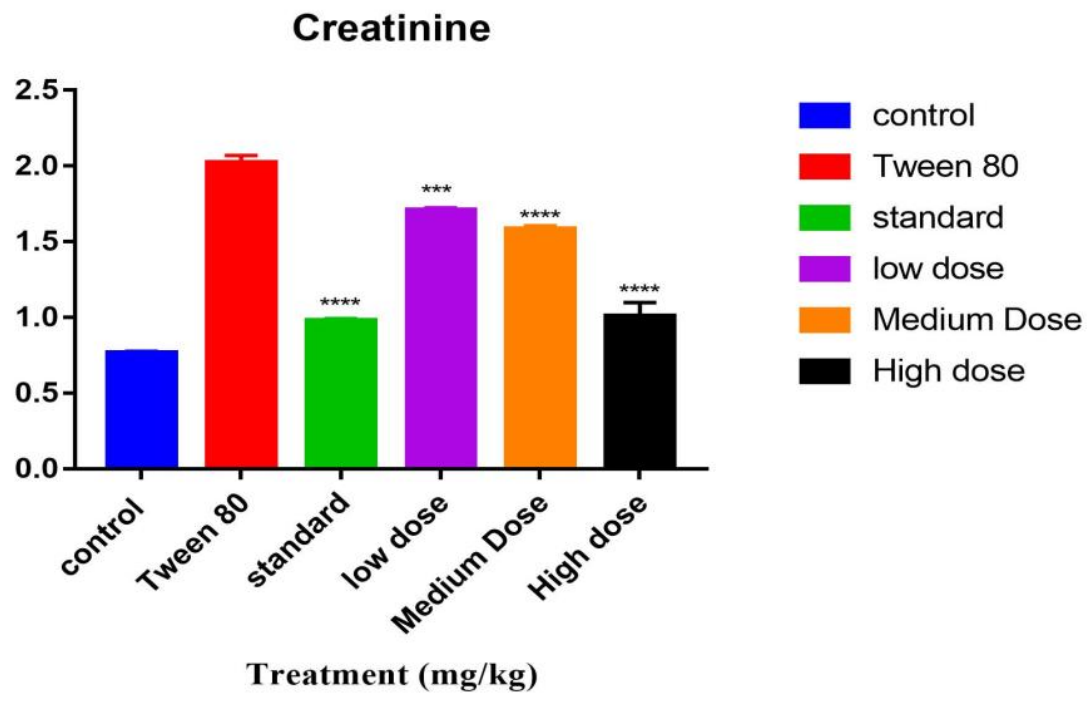

Figure 6: Total creatinine level in different treatment group. 


\section{Total Protein}

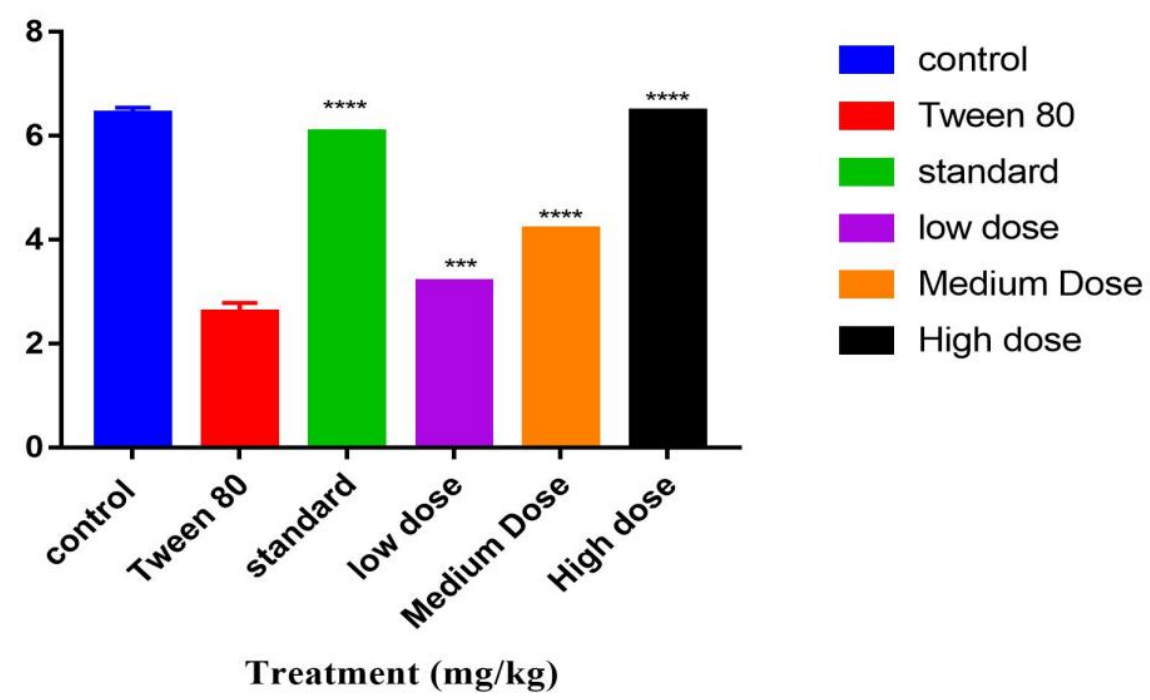

Figure 7: Total protein level in different treatment groups.

\section{Serum Albumin}

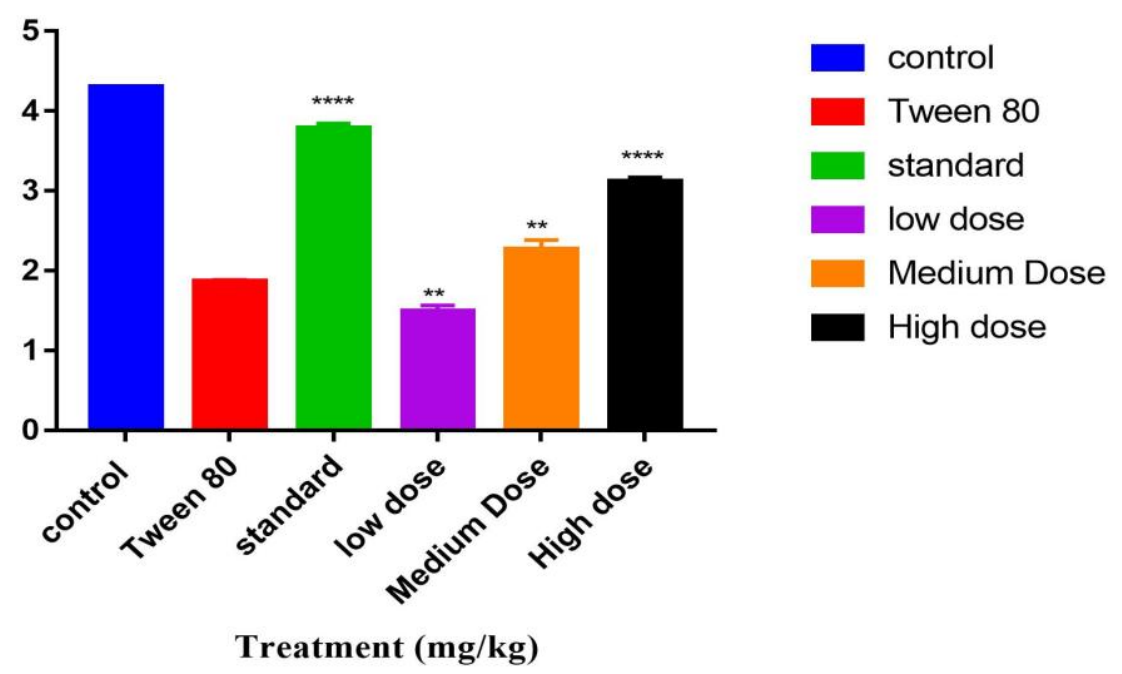

Figure 8: Total serum albumin level in different treatment groups.

\section{A/G Ratio}

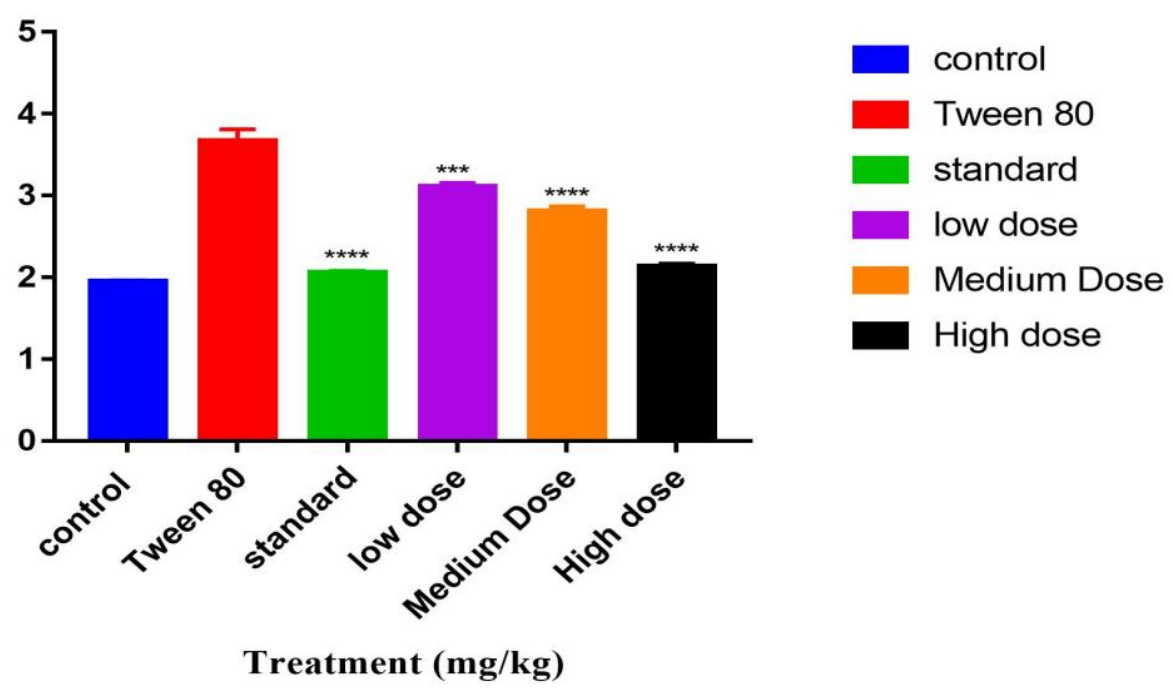

Figure 9: A/G Ratio level in different treatment groups. 
The observation suggested that EE in $400 \mathrm{mg} / \mathrm{kg}$ b.w. dose is highly efficient in maintaining all the biochemical parameters in laboratory animals.

\section{DISCUSSION}

The present study was aimed at discovering the antidiabetic properties of Leucas cephalotes in alloxan induced diabetes. In the traditional days Leucas cephalotes was used alone or in with other remedial measures against $\mathrm{DM}^{7}$. Alloxan causes a massive reduction in insulin release by the destruction of the $\beta$ cells of the islets of langerhans, inducing hyperglycaemia. The rats (induced by alloxan) showed a persistent rise in BGL after $7^{\text {th }}, 14^{\text {th }}$ and 21 th day with the symptomatic features of $\mathrm{DM}^{8}$. The extract of Leucas cephalotes was not able to decrease the BGL in alloxaninduced diabetic rats, on single dose administration which concludes that the extracts are ineffective ${ }^{9}-{ }^{11}$. The significant activity was attained on repeated administration of the EE from day $7^{\text {th }}$ by controlling the increased BGL compared with other group. The EE on repeated administration reduced the glucose level in diabetic rats on $7^{\text {th }}, 14^{\text {th }}$ and $21^{\text {nd }}$ days as compared to diabetic control.

While in case of EE (400 mg/kg) it has shown a significant reduction in blood glucose level on $7^{\text {th }}$ day, $14^{\text {th }}$ day and $21^{\text {st }}$ day.

\section{CONCLUSION}

In conclusion, EE had shown a significant hypoglycaemic activity in normal rats, against alloxan induced rats. Ethanolic extract of Leucas cephalotes exhibited antidiabetic potential on $0,7,14$ and 21 st day of treatment.

\section{Conflict of interest}

The authors declare no conflict of interest.

\section{Acknowledgement}

The author thanks the management of IFTM University, Moradabad for necessary facilities.

\section{REFERENCES}

1. Pietraszek A, Gregersen S, Hermansen K. Alcohol and type 2 diabetes. A review. Nutr Metab Cardiovasc Dis 2010; 20(5):366-375.

2. Chelliah A, Burge MR. Hypoglycaemia in elderly patients with diabetes mellitus: causes and strategies for prevention. Drugs Aging. 2004; 21(8):511-530.

3. Hader C, Graf-Gruss R. Diabetes im Alter. DDG Praxis Leitlinie. Diabetologia. 2007; 2:202-206.

4. Diamond G.A., Bax L., Kaul S. Uncertain effects of rosiglitazone on the risk for myocardial infarction and cardiovascular death. Ann. Intern. Med. 2007; 147: 578-581

5. Kumar A. Insulin guidelines: taking it forward. Medicine Update (API India). 2010; 20:127-30.

6. Mathew E, Ahmed M, Hamid S, Abdulla F, Batool K. Hypertension and dyslipidaemia in Type 2 diabetes mellitus in United Arab Emirates. Australas Med J. 2010; 3(11):699706.

7. Carpenter MW, Coustan DR: Criteria for screening tests for gestational diabetes. Am J Obstet Gynecol 1982; 144:768773.

8. Trapp CB, Barnard ND. Usefulness of vegetarian and vegan diets for treating type 2 diabetes. Curr Diab Rep. 2010; 10:152-158.

9. Yazdanparast R, Esmaeili MA, Helan JA. Teucrium polium extract effects pancreatic function of streptozotocin diabetic rats: a histopathological examination. Iran Biomed J. 2005; 9(2):81-85.

10. Jarald E, Joshi SB, Jain DC. Diabetes and herbal medicines. Iran J Pharmacol Ther. 2008; 7(1):97-106.

11. Bhushan MS, Rao CHV, Ojha SK, Vijayakumar M, Verma A. An analytical review of plants for anti diabetic activity with their phytoconstituent \& mechanism of action. Int $\mathbf{J}$ Pharm Sci Res. 2010; 1(1):29-46. 